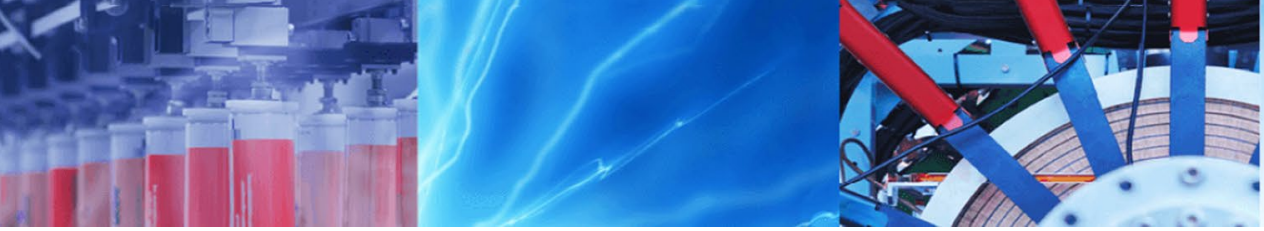

Case Study

\title{
Green energy technology from buriti (Mauritia flexuosa L. f.) for Brazilian agro-extractive communities
}

\author{
Munique Gonçalves Guimarães ${ }^{1}$ Rafael Benjamin Werneburg Evaristo ${ }^{1} \cdot$ Augusto César de Mendonça Brasil $^{2}$. \\ Grace Ferreira Ghesti ${ }^{1}$ iD
}

Received: 1 September 2020 / Accepted: 27 January 2021 / Published online: 6 February 2021

(C) The Author(s) 2021 OPEN

\begin{abstract}
The present work analyzed the energy generation potential of Buriti (Mauritia flexuosa L. f.) by thermochemical reactions. The experimental part of the study performed immediate analyses, elemental analyses, lignocellulosic analysis, thermogravimetric analysis, calorific values, and syn gas concentrations measurements of the gasification of Buriti in a fixed-bed reactor. Additionally, numerical simulations estimated the syn gas concentrations of the gasification reactions of Buriti. The immediate analysis showed that Buriti has the highest ash content (4.66\%) and highest volatile matter content (85\%) compared to other Brazilian biomass analyzed, but the higher heating value was only $18.28 \mathrm{MJ}_{\mathrm{kg}} \mathrm{k}^{-1}$. The elemental analysis revealed that the oxygen to carbon ratio was 0.51 while hydrogen to carbon ratio was 1.74 , indicating a good thermal conversion efficiency. The Lignocellulosic analysis of Buriti resulted in a high content of holocellulose (69.64\%), a lignin content of $28.21 \%$ and extractives content of $7.52 \%$. The thermogravimetry of the Buriti indicated that the highest mass loss (51.92\%) occurred in a temperature range between $150^{\circ} \mathrm{C}$ and $370^{\circ} \mathrm{C}$. Lastly, the experimental gasification study in a fixed-bed updraft gasifier resulted in syn gas concentrations of $14.4 \%$ of $\mathrm{CO}, 11.5 \%$ of $\mathrm{CO}_{2}$ and $17.5 \%$ of $\mathrm{H}_{2}$ while the numerical simulation results confirmed an optimal equivalence ratio of 1.7 to maximize $\mathrm{CO}$ and $\mathrm{H}_{2}$ concentrations. Therefore, based on the results presented by the present work, the gasification process is adequate to transform Buriti wastes into energy resources.
\end{abstract}

Grace Ferreira Ghesti, ghesti.grace@gmail.com | ${ }^{1}$ Laboratory of Brewing Bioprocesses and Catalysis To Renewable Energy, Chemistry Institute, University of Brasilia, Brasilia-DF 70910-900, Brazil. Energy Engeneering Department, Faculty of Gama, University of Brasilia, Brasilia-DF 70910-900, Brazil. 


\section{Graphic abstract}

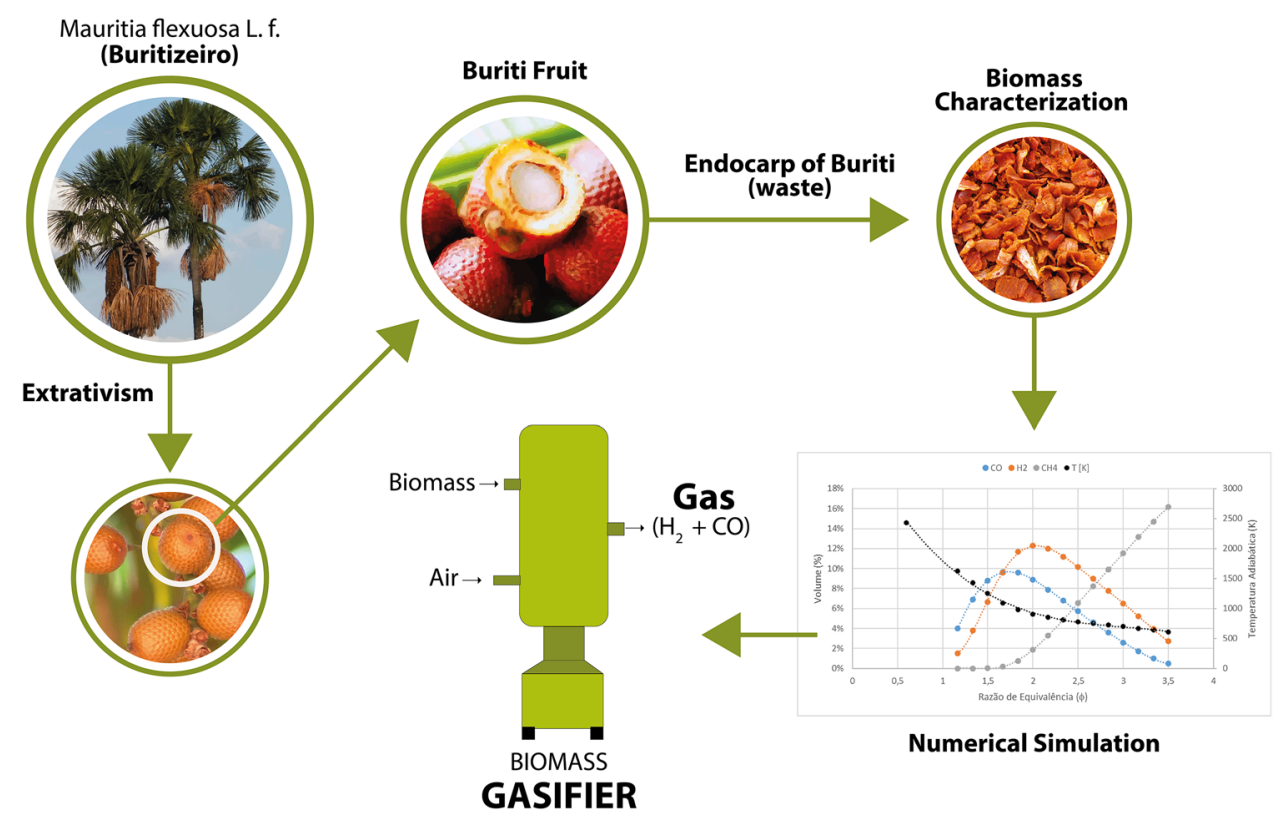

Keywords Energy harnessing · Gasification · Agricultural residue · Buriti endocarp · Bioenergy

\section{Introduction}

The growing and diversified waste production, linked to intensive urbanization and the use restriction of free areas, leads to proposing viable and economical management solutions, in order to potentialize reuse and reduce waste production [1]. Growing importance in the use of renewable energies (biomass, solar, wind, etc.) aiming sustainable development and circular economy promotion [2]. Biomass used for energy production stands out in this integration context, not only in a more sustainable production context, but also in an entire waste management chain. Among several biomass conversion technologies, thermochemical processes (pyrolysis, gasification, combustion, hydrothermal carbonization, roasting) point to diverse possibilities, gasification technology, add to those, has been considered a more attractive process in order to convert biomass with better conversion efficiency [3] into various final products, such as: biochar, bio-oil and synthesis gas [4].

Some studies on gasification address the use of woody materials as raw material for producing synthesis gas (since it is a biomass type already widely used for several other products), such as its use in downdraft gasifiers [5-8]. However, other biomass types can also be inserted in this conversion chain, being clearly evaluated aspects regarding nature, chemical composition, environmental, in addition to economic and logistic factors linked to their origin [4]. Thus, several inputs profiles are studied towards making other biomass purveyance feasible, such as: agricultural crops waste [6], forest waste [7], waste generated in agro-industrials steps, organic portion of the urban solid waste (USW) [8] and animal fertilizers [9].

A resource that assists in viability evaluation of a certain biomass in conversion process is simulation, especially for gasification, these processes are already widespread. The mathematical modeling aims to analyze thermochemical processes during gasification, assessing the main input variables influence, such as the fuel (biomass) characteristics, evaluating its effects on generated products properties, according to reaction conditions [10]. A zero dimension (OD) mathematical model for continuous flow of biomass gasification in fixed bed gasifiers was developed and studied in order to assist the decision making about the process (type of reactor, better conditions based on yield). This model was also used to optimize operational conditions (scale up, industrial control strategies and performance evaluation after changing operational conditions) and predict a possible experimental result from a thermochemical process.

Buriti (Mauritia flexuosa L. f.) belonging to Arecaceae family is considered a Brazilian palm tree, which is found mainly in waterlogged and wet areas in Brazil's Midwest, North and Northeast regions. Presenting diversified 


\section{Fruit of the open buriti}

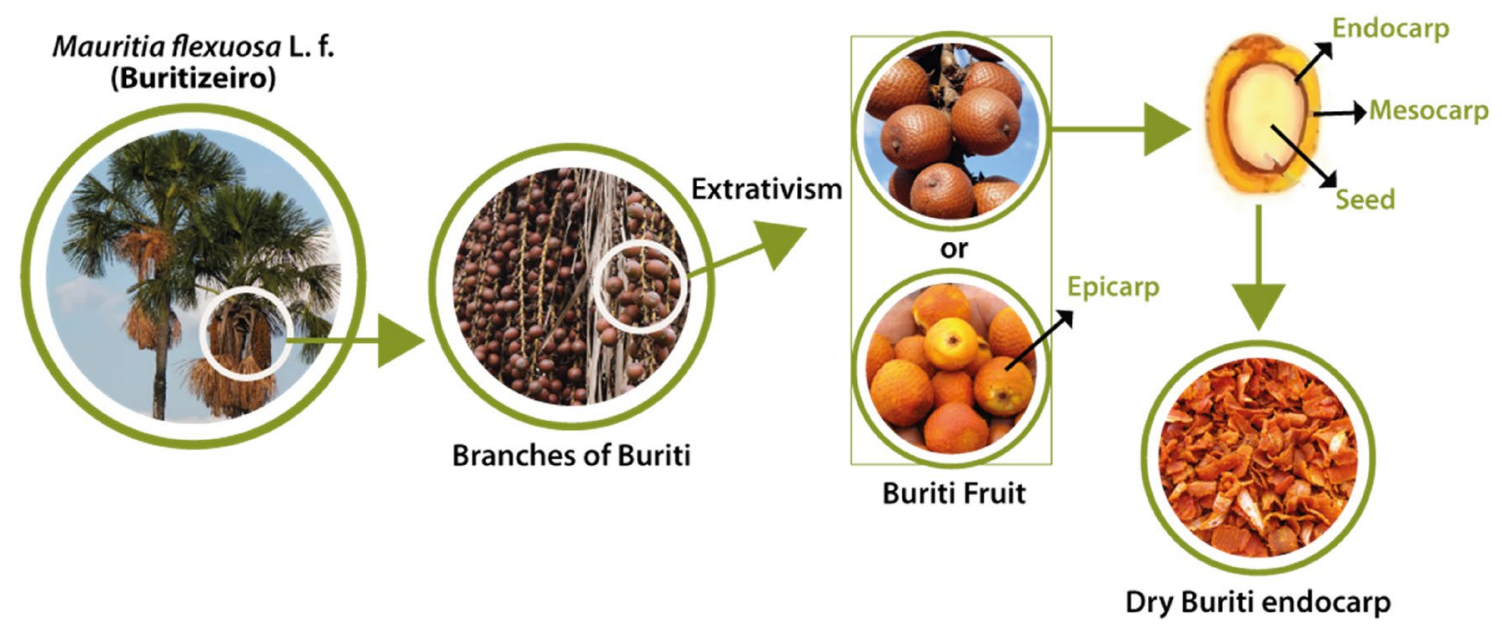

Fig. 1 Buriti fruit origin and structure

composition in each one of its parts, this plant has a multitude of applications in food industry, cosmetics production, crafts and fuels [11]. The fruit maturation occurs from October to March in female plants and presents two colors type at the mesocarp (orange and reddish) [12]. Its fruit is elliptical to oval and comprises pericarp (peel), mesocarp (pulp), endocarp (lignocellulosic tissue from seed bark) and endosperm (seed) [13], as shown in Fig. 1.

Buriti fruits are economically exploited for a variety of purposes, such as extraction of edible oils (powerful vermifuge [13]), cosmetics fabrication (burn treatment [14], sunscreen [12, 14, 15], lotions [12]), beverage production (juices [12], liquor), ice creams [12, 15], sweets [12] or dehydrated pulp [12]. This plant demand is growing, as the largest fruit producers in Brazil (North and Northeast regions) harvest already an average of 70,000 tons per crop. From its processing, waste is generated, like its endocarp with a lignocellulosic structure, which has already been studied as possible source for second generation ethanol production. The endocarp is one of this fruit parts that has no industrial destination and, due to its composition, can be inserted in energy reuse process [15].

Buriti fruits incorporate a series of other Brazilian native fruits commercially exploited by rural extractive settlements, which are organized into cooperatives for harvesting and marketing. These communities live in locations with difficult access to electricity and rely on diesel generators to supply their needs [15].

In light of these considerations, the inclusion of agroindustrial waste in energy scenario and biomass gasification technology as means of harnessing energy, this paper is divided: characterization of the the Buriti endocarp, evaluate its feasibility for gasification process through mathematical simulation and, finally, to proceed experimental gasification tests on a pilot scale. So that it is possible to provide new process data for a complete assessment about the use of agro-industrial waste in agro-extractive communities' energy supply.

\section{Materials and method}

\subsection{Materials}

The experiments proceeded with the Buriti endocarp (called EB henceforth), obtained through the processing of a farm located in Goiás state, Brazil's Midlewest region. This plantation belongs to the Network Marketing Partnership of Family Farmers and Collectors of Cerrado, known as COOPCERRADO or Cerrado Emporium (Empório do Cerrado), which produces, manufactures and sells Cerrado fruits, such as Baru, Jatobá, Buriti, Pequi, and others. For sample preparation, the forest residue was ground and standardized using a sieve shaker, brand Betel with sieves 40 ABNT/ASTM (40 Mesh) for gasification process and 60 ABNT/ASTM ( 60 Mesh) for immediate analysis and characterization process. The agitator was programmed for $20 \mathrm{~min}$ and vibrations of $7 \mathrm{rpm}$ and the samples were stored in polyethylene bags at room temperature, protected from light.

\subsection{Immediate analysis}

Immediate analyses were performed according to the Brazilian Association of Technical Standards (ABNT, NBR $8112 / 86)$ with adaptations. These analyses provide the fractions by weight of moisture, volatiles, ash and fixed carbon. 


\subsection{Elemental analysis}

Elemental analyses were performed according to the Brazilian Association of Technical Standards (ABNT, NBR E775, E777, E778 and E870). These analyses provided the fractions by weight of the main elements in biomass composition. Carbon $(\mathrm{C})$, nitrogen $(\mathrm{N})$ and hydrogen $(\mathrm{H})$ were determined in a Perkin Elmer 2400 Series II CHN Elemental Analysis equipment. Other components were determined using a Shimadzu X-ray Fluorescence (XRF) spectrometer (model EDX 720) with Rhodium tube as X-ray source. Oxygen $(O)$ was calculated from the results obtained from $\mathrm{CHN}$ and XRF/EDX.

\subsection{Lignocellulosic analysis}

Soluble and insoluble lignin contents were determined using laboratory analytical procedures from the National Renewable Energy Laboratory (NREL, LAP 003 and 004/1995). In addition, total extractives were quantified in ethanol: toluene $(2: 1, \mathrm{v} / \mathrm{v})$ accordingly to TAPPI Standards \& Methods (T 204 om-88) with adaptations. The holocellulose content without extractives was calculated by subtracting the full content of lignin and ash without extractives.

\subsection{Thermal analysis (TGA/DTG/DTA)}

Thermogravimetric analysis (TGA)/Derivative Thermogravimetry (DTG)/Differential Thermal Analysis (DTA) curves were obtained in a TA Instruments SDT 2960 analyzer using $10^{\circ} \mathrm{C} \mathrm{min}^{-1}$ of heating rate from room temperature to $1000{ }^{\circ} \mathrm{C}$ and $100 \mathrm{~mL} \mathrm{~min}{ }^{-1}$ of synthetic air flow ( $80 \pm 0.5$ of $\mathrm{N}_{2}$ and $20 \pm 0.5$ of $\mathrm{O}_{2}$-purity $>99.999 \%$ ) or nitrogen (purity $>99.999 \%$ ).

\subsection{Calorific value}

The determination of higher heating value (HHV) of the studied biomass was established according to the Brazilian Association of Technical Standards (ABNT, NBR 8633/84) using an IKA calorimeter C 2000 BASIC.

\subsection{Numerical simulation}

A simplified OD model was implemented in Engineering Equation Solver (EES) to simulate the Buriti biomass air gasification reaction. The model supposed that the biomass would entirely react into gas. Additionally, chemical equilibrium state was assumed, and the influence of equivalence ratio on produced gas composition was evaluated, while ash content and tar reaction were neglected.
The numerical model applied in this study is similar to the model previously published by Itai et al. [16].

\subsection{Gasification experiments and gas analysis}

The gasification process was performed in a small-scale ( $7 \mathrm{~L}$ capacity) counter-current (updraft) gasifier made of stainless steel. A ceramic fiber blanket was installed to enhance heat distribution. Experiments started with $400 \mathrm{~g}$ of $\mathrm{EB}$ and $10 \mathrm{~mL}$ of ethanol to initialize the burning process ( $20 \mathrm{~min}$ ). After that more $400 \mathrm{~g}$ of EB were added and the reactor top was closed for the gasifying process to occur (air flow was constant at $3.5 \mathrm{Nm}^{3} \mathrm{~h}^{-1}$ ). The produced gases were collected $20 \mathrm{~min}$ after the closure of the reactor top, and two other collections were made with 10-15 min between the sampling. The reactor design and the detailing process of experiments can be found in a report previously published by Evaristo et al. [17].

To perform the collected gases analysis, a GC-17 equipment from Shimadzu was used with following conditions: Carboxen 1010-Plot column, splitless injection, temperature injector of $200^{\circ} \mathrm{C}$, pressure of $15 \mathrm{kPa}$, total

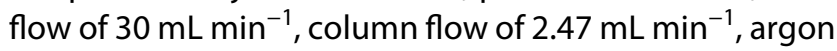
(purity $>99.998 \%$ ) as carrier gas and a thermal conductivity detector (TCD). To determine concentration $(v / v)$ of the collected gases in the gasifier, linear standard curves were prepared by diluting each gas volume to be analyzed with pure $\mathrm{N}_{2}$ in a gastight Hamilton syringe. All linear equations and determination coefficients $\left(R^{2}\right)$ were obtained from peak intensity versus the gas volumetric concentration. Evaristo et al. [17].

The Fig. 2 presents a flowchart with the main steps developed in this work.

\section{Results and discussion}

\subsection{Immediate analysis}

The biomass composition and choice of the conversion route are intertwined. Certain biomasses are more suitable for specific processes than others, having their physicochemical characteristics in sight, a best exploitation with maximum biomass yield can be achieved. Thus, Table 1 presents the Buriti endocarp main characteristics (immediate and elementary analysis) and it also presents examples of other residues used in the gasification process.

EB moisture content is close to the other residue values listed in Table 1, except to Acai Seeds' value [18-20]. Moisture is especially important for thermochemical process since it is a variable associated with the intrinsic characteristics of initializing the heating process. Biomass with high moisture content spend more energy during the first 


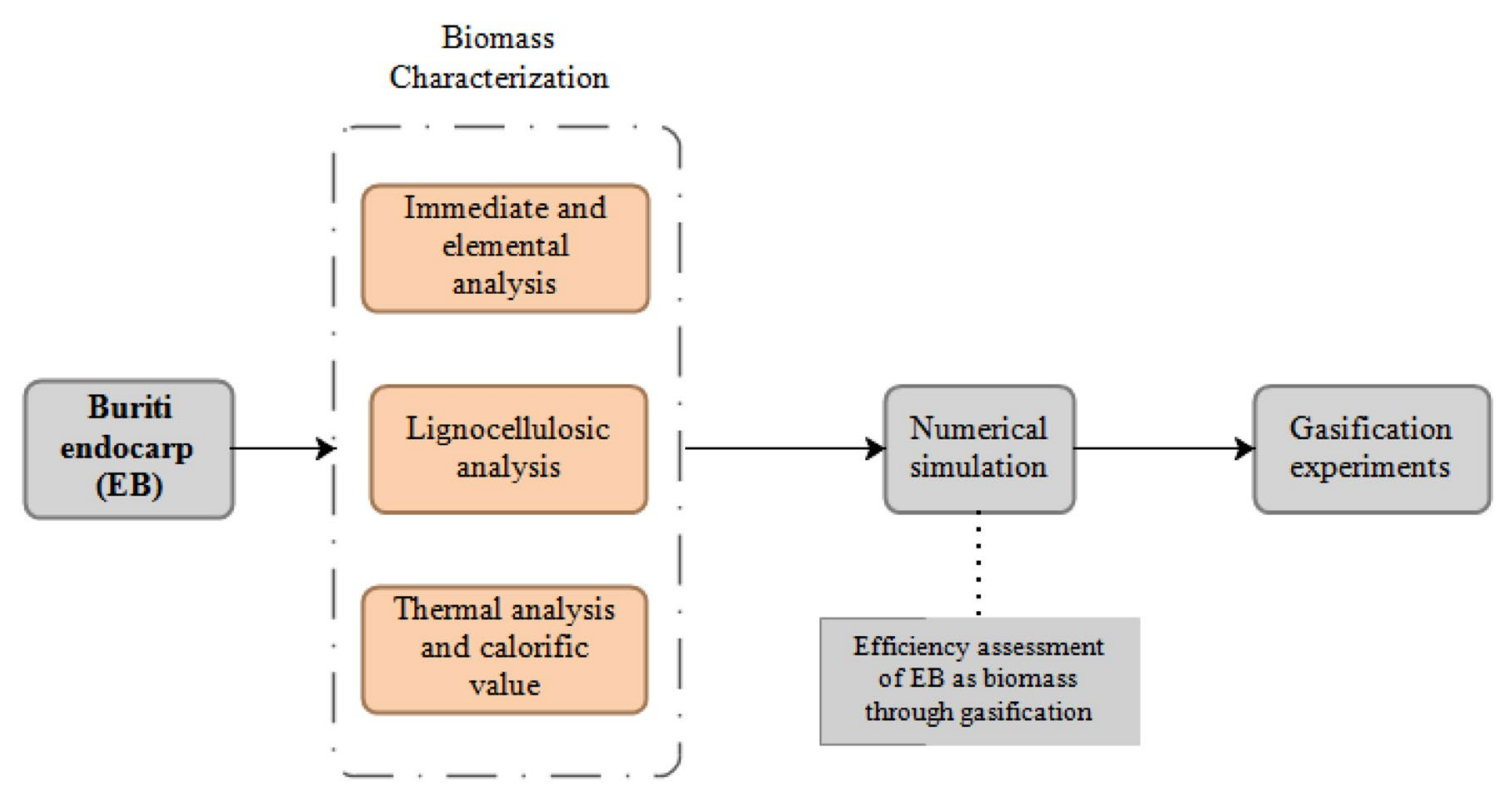

Fig. 2 Flowchart of the experimental procedure that was performed in this study

Table 1 Proximate and ultimate analysis of Endocarp of Buriti (EB), Acai seeds (ACS), Pine bark (PB), Almond shells (AS) and Coconut shell (CS)

\begin{tabular}{lcccrr}
\hline Analysis & EB (This work) & ACS [16] & PB [18] & AS [19] & CS [20] \\
\hline $\begin{array}{l}\text { Moisture (as } \\
\text { is) }\end{array}$ & 8.81 & 15.48 & 10.10 & 7.00 & 3.00 \\
$\begin{array}{l}\text { Proximate analysis (wt\%, dry basis) } \\
\text { Volatile mat- }\end{array}$ & 85.00 & 79.93 & 70.18 & 78.23 & 77.94 \\
$\quad$ ter & & & & & \\
Ash & 4.66 & 1.39 & 0.95 & 2.71 & 0.65 \\
Fixed carbon & 10.34 & 18.68 & 28.87 & 19.06 & 18.06 \\
Ultimate analysis (\%) & & & & \\
C & 53.30 & 46.04 & 55.49 & 45.64 & 54.68 \\
H & 7.80 & 6.77 & 5.56 & 6.19 & 7.15 \\
N & 1.10 & 7.99 & 0.17 & $<0.05$ & 0.58 \\
O & 36.12 & 38.38 & 37.74 & 45.43 & 39.12 \\
H/C ratio* & 1.74 & 1.75 & 1.19 & 1.62 & 1.56 \\
O/C ratio* & 0.51 & 0.63 & 0.51 & 0.75 & 0.54 \\
Higher heat- & 18.28 & 18.14 & 19.99 & - & 20.19 \\
ing value & & & & & \\
(MJ Kg & & & & & \\
\hline
\end{tabular}

*Molar atomic ratio

step of themo-conversion, when this energy is destined for vaporizing the water implicating in the reduction of total process efficiency [21]. Analyzing the reactions involved in gasification process it might be observed that water participates in the reduction zone through water-gas shift reaction and steam methane reforming that contribute to $\mathrm{H}_{2}$ production. That way moisture does not entirely represent an issue to thermo chemical process since it will participate in part with the resulting syn gas profile, but before that the first impact about higher moisture is associated with reduction in higher heating values, thus, it is always a parameter that must be well known and regulated to gasification operation [22]. That way is recommended for biomass to have moisture between 5 and $30 \%$ [21]. Moisture is also associated with storage standards since high moisture content implicate in the proliferation of micro-organisms that deteriorate the feedstock, that way pre-treatment like drying procedures are recommended to maintain biomass stability during transportation or storage.

As for volatile materials content, EB material (85\%) is higher than the ones related to almond shells, coconut shell, acai seeds and pine bark (approximately $78 \%, 78 \%$, $80 \%$ and $70 \%$, respectively). The value found is similar to wood ones (70-85\%) [17] and result in higher gas production in combustion. Thus it is expected to burn faster and to present greater tar production and less flame stability [17].

Buriti endocarp showed ash content (4.66\%), this does not impact the process efficiency, as it will not interfere with the calorific value or heat transfer. It would not even result in clogging and scale deposits in the equipment. Besides, there are studies in literature that report various uses of residual ash as sorbents, building materials and fertilizers, fuel supplements in energy production or industrial applications, such as burning clay bricks and cement kilns [3].

EB fixed carbon content (10.34\%) is the smallest among all listed biomasses. Thereby this result corroborates the volatile content result, indicating that its combustion 


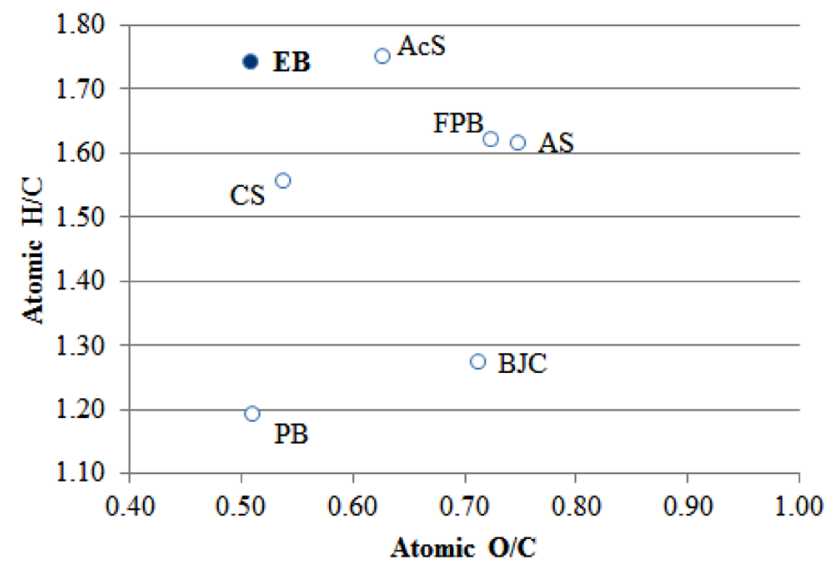

Fig. 3 Van Krevelen diagram of atomic ratios for biomass ( $E B$ Endocarp of Buriti, ACS Açai Seeds, PB Pine Bark, AS Almond Shells, CS Coconut Shells, FPB Fruit Peels of Baru, BJC Bark of Jatoba-do-Cerrado tree)

will be faster and the biomass residence time inside the reactor will be shorter, and so a constant biomass feed that can be controlled by generated products profile (gas concentration, flame intensity, flame permanence) will be necessary [23].

Elemental analysis showed a carbon content of 53.3\%, similar to other referenced biomasses, as well the content of hydrogen (7.8\%), nitrogen (1.1\%) and oxygen (36.1\%). Based on these data, especially carbon content and O/C ratio, good conversion efficiency is expected (and greater resistance to thermal degradation), this being important for fossil fuels production [24]. The high carbon content and the respective fixed carbon content may also favor obtaining coal intended for other applications, or even for increasing energy density and application in gasification technology itself [25]. The low nitrogen content can be considered a positive aspect for lignocellulosic biomasses submitted to thermochemical processes, as they contribute to reduce environmental impact and air pollution caused by the formation of subproducts as $\mathrm{NO}_{\mathrm{x}}$ compounds [26].

For thermochemical conversion processes $\mathrm{H} / \mathrm{C}$ and $\mathrm{O} / \mathrm{C}$ ratios are more important than just the appropriate $\mathrm{H}, \mathrm{O}$ and $\mathrm{C}$ content. The higher values of $\mathrm{H} / \mathrm{C}$ and $\mathrm{O} / \mathrm{C}$ result in lower calorific values due to the lower amount of energy contained in the carbon-oxygen and carbon-hydrogen bonds compared to carbon-carbon bonds, which is characteristic of biomass represented by fixed carbon content. Figure 3 shows correlations between hydrogen/ carbon $(\mathrm{H} / \mathrm{C})$ and oxygen/carbon $(\mathrm{O} / \mathrm{C})$ ratios for several/ different biomasses in the Van Krevelen diagram. These proportions are associated with aromaticity degree $(\mathrm{H} / \mathrm{C})$ and carbonation $(\mathrm{O} / \mathrm{C})$ of the samples [27]. As can be seen in Fig. 3 EB is positioned in the first quadrant of the Van
Krevelen diagram, located close to the acai seeds (AcS). The biomasses in Table 1 were added to the diagram along with two other biomasses from Brazilian Cerrado, the fruit peels of baru (FPB) and bark of Jatoba-do-Cerrado tree (BJC) [17]. In this simple analysis, it is possible to observe that all biomasses associated with seed or fruit peels, as is the case of $E B, A C S, F P B, A S$ and $C S$ have higher $\mathrm{H} / \mathrm{C}$ values than biomass of woody origin as is the case of $\mathrm{PB}$ and BJC (two tree barks). This proximity may be related to such biomasses constitution, associated precisely with their origin, even so, other biomasses would need to be studied in order to have a statement that adds the diagram analysis, i.e. studies of chemical composition.

The Buriti endocarp presented a HHV of $18.3 \mathrm{MJ} \mathrm{kg}^{-1}$, the other biomass (ACS, PB and CS) used for comparison ranged from 18 to $20 \mathrm{MJ} \mathrm{kg}^{-1}$. According to Rocha et al. (2017) [28], HHV is directly related to the fixed carbon content (where carbon content in higher temperatures will directly participate in syngas formation) and is also associated with the volatile matter (favorable in pyrolysis zone) and ash content, regardless of the biomass used [17, 20]. According to Nogueira and Lora (2003) [29] lignocellulosic biomass with high levels of volatile matter tend to burn faster requiring operational adjustments in the reactor since it will take less residence time, that way besides some of those variations in immediate analysis values the process can be modified. In view of these correlations, it was observed that EB presented the lowest fixed carbon content and highest volatile matter and ash content compromising the HHV observed. This analysis by itself does not represent the actual performance of those biomass when submitted to a certain kind of process since other compositional and process variables will also affect the final results.

The immediate analysis results show that Buriti endocarp has desired characteristics and its use in thermochemical processes is indicated [30]. Based on Table 1 data, the gasification mathematical modeling proceeded in order to access a profile of generated gases. The comparison with other biomasses was also reported and presented in Table 4.

Table 2 Lignocellulosic biomass composition

\begin{tabular}{llcll}
\hline $\begin{array}{l}\text { Analysis } \\
\text { (wt.\%) }\end{array}$ & $\begin{array}{l}\text { Endocarp } \\
\text { buriti (This } \\
\text { work) }\end{array}$ & $\begin{array}{l}\text { Acai seeds } \\
{[35]}\end{array}$ & $\begin{array}{l}\text { Almond } \\
\text { shells } \\
{[19]}\end{array}$ & $\begin{array}{l}\text { Coconut } \\
\text { shells } \\
{[33]}\end{array}$ \\
\hline Lignin & 28.21 & 37.16 & 33.00 & 44.77 \\
Holocellulose & 69.64 & 56.00 & - & 54.96 \\
Extractives & 7.52 & 2.30 & - & 0.27 \\
\hline
\end{tabular}




\subsection{Lignocellulosic analysis}

Lignocellulosic analysis is presented in Table 2. Buriti endocarp presents a high content of holocellulose when compared to values of almond shells [27] (56\%) and coconut shells [31] (54.96\%); it also presents a similar lignin content $(28.21 \%)$ to almond shells $(33.00 \%)$ and an inferior value compared to acai seeds (37.16\%) and coconut shells (44.77\%). Buriti endocarp extractives content $(7.52 \%)$ is superior to the ones presented in acai seeds $(2.3 \%)$ and coconut shells (0.27\%). Rodrigues et al. [15] also studied Buriti endocarp, finding lignin and holocellulose values of $24.50 \%$ and $44.36 \%$, respectively. As biomasses vary in different ways, fixed values were not found for each analysis, but a range of values was. This happens because each plant final constitution is subject to various influence types, such as climate, soil pH, harvest season, etc. It is important to highlight that lignocellulosic composition of each type of biomass will influence the burning process (affecting its calorific value), since not only the content of each of its components will make difference, but also structural morphology of its distribution will affect the process. In that way, even biomasses with similar composition may have different conversion profiles due to its origins, woods, tree barks, fruit shells, roots, seeds, tree pruning, among many other examples of lignocellulosic biomass [32].

Rambo et al. [33] report that higher calorific values result from samples with higher lignin and extractives content because they have less oxygen, that is, lower O/C values, than the polysaccharides present in holocellulose (cellulose and hemicellulose).

Lignin and holocellulose contents found for the biomass analyzed in this study are favorable to bioenergy generation through thermochemical processes, especially by gasification. According to Sikarwar et al. [21],

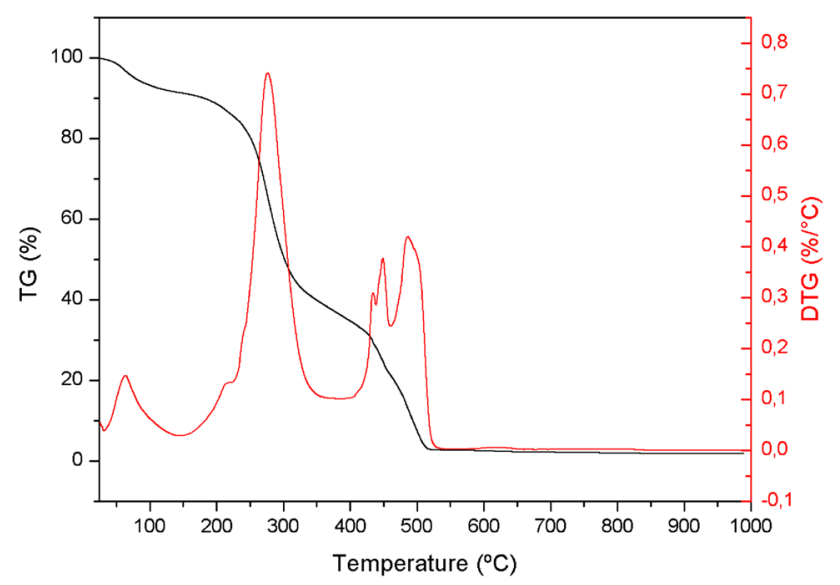

Fig. 4 Buriti Endocarp TG/DTG
Table 3 Degradation zones of EB thermal analysis in synthetic air

\begin{tabular}{lccc}
\hline $\begin{array}{l}\text { Degradation } \\
\text { zones }\end{array}$ & Mass loss (\%) & $\begin{array}{l}\text { Temperature } \\
\text { range }\left({ }^{\circ} \mathrm{C}\right)\end{array}$ & $\begin{array}{l}\text { Temperature } \\
\text { Maximum }\left({ }^{\circ} \mathrm{C}\right)\end{array}$ \\
\hline 1 & 8.42 & $31-150$ & 62.52 \\
2 & 51.92 & $150-370$ & 276.59 \\
3 & 18.65 & $370-460$ & 449.83 \\
4 & 18.24 & $460-510$ & 482.56 \\
\hline
\end{tabular}

the proportion of cellulose and hemicellulose is directly related to the yield of gaseous products. Therefore, the greater the proportion of cellulose and hemicellulose to lignin in a given biomass, the greater the favoring of the formation of gases inside the reactor. Previous knowledge about the main physical and chemical characteristics of the Buriti endocarp was essential for planning this residue use. [34].

\subsection{Thermal analysis}

Thermogravimetric (TG) analysis was performed to determine biomass thermal stability through mass losses over rising temperature and residual (unburned) material present in coal sample, in order to improve the final use of any sample produced during any fuel combustion [35]. In Fig. 4 and Table 3, five significant losses can be seen.

The first decomposition zone in TG/DTG curve is related to $31-150{ }^{\circ} \mathrm{C}$ range, where there is loss of chemically and physically adsorbed water in EB structure and loss of other substances of low molar mass, equivalent to a mass loss of $8.42 \%$ [36]. This value is consistent with the one found in moisture immediate analysis, $8.81 \%$. The temperature maximum peak of this zone was $62.52^{\circ} \mathrm{C}$ for EB.

The second decomposition zone in TG/DTG curve corresponds to $160-370^{\circ} \mathrm{C}$ temperature range, in which the greatest mass loss, of $51.92 \%$, is observed, coinciding to: hemicellulose degradation that occurs between $160{ }^{\circ} \mathrm{C}$ and $260{ }^{\circ} \mathrm{C}$ [36]; beginning of cellulose degradation between $240^{\circ} \mathrm{C}$ and $370^{\circ} \mathrm{C}$; and beginning of lignin degradation in $150-300^{\circ} \mathrm{C}$ range, where the ether and aromatic bonds break, close to $300^{\circ} \mathrm{C}$ [37]. Hemicelluloses have a simpler and less organized structure (amorphous conformation) when compared to cellulose that has a crystallin and organize conformation. Such molecular differences result in the profile of degradation observed where a much more organize and stable structure tend to be more thermal resistant (cellulose) and a more non-organize structure with lower molecular weight (hemicelluloses) decompose first. In correlation with the application studied in this work, the thermo-degradation of hemicelluloses in lowest temperatures tend to form non-combustible gases and tar 


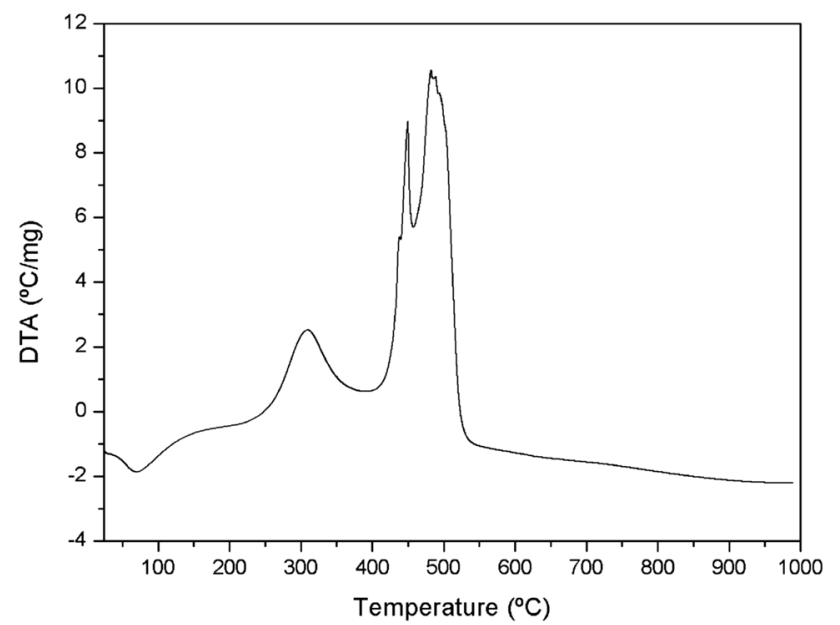

Fig. 5 Buriti Endocarp DTA

during the burning process.[21] EB showed a temperature maximum peak at $276.59^{\circ} \mathrm{C}$ in DTG curve zone.

The third decomposition zone of TG/DTG curve is related to cellulose and part of lignin degradation, corresponding to $370-460{ }^{\circ} \mathrm{C}$ range in which a mass loss of $18.65 \%$ is observed, when an intense scission on celluloses polymer chains (depolymerization) happens, accompanied by lignin decomposition [38], with cellulose decomposition being the dominant process at this stage. Cellulose is responsible for the production of most flammable volatile compounds [39]. EB showed a temperature maximum peak at $449.83^{\circ} \mathrm{C}$ in DTG curve.

The fourth decomposition zone of TG/DTG curve corresponds to $460-510^{\circ} \mathrm{C}$ range, which presents $18.24 \%$ mass loss, related to the end of lignin degradation, when carbon-carbon bonds are broken at temperatures between 370 and $400^{\circ} \mathrm{C}$. The temperature maximum peak of this zone was $482.56^{\circ} \mathrm{C}$ for EB. By the end of these steps, the resulting residue consisted of $1.87 \%$.

DTA curves of Fig. 5 showed 4 striking peaks. The first one at a $69.66{ }^{\circ} \mathrm{C}$ temperature, featuring endothermic process related to the following events: water evaporation and decomposition of low molecular weight organic compounds. And the remaining 3 peaks at $308.52{ }^{\circ} \mathrm{C}$, $443.18^{\circ} \mathrm{C}$ and $482.56^{\circ} \mathrm{C}$ temperatures characterize predominantly exothermic processes that correspond to organic matter combustion/pyrolysis related to heavier organic chains compounds.

\subsection{Numerical gasification simulation}

Numerical simulation results were compared with simulations results published by Itai et al. [16], Pérez et al. [40], Masmoudi et al. [27]. Table 4 presents values comparison of $\mathrm{CO}, \mathrm{CO}_{2}, \mathrm{H}_{2}$ and $\mathrm{CH}_{4}$ concentrations, simulated for Buriti when the equivalence ratio condition resulted in maximum $\mathrm{CO}$ concentration and respective works comparison.

The present work results refer to numerical gasification model in chemical equilibrium described by Itai et al. [16] Values presented by Itai et al. [16] refer to numerical modeling results of Acai seed gasification, Masmoudi et al. [27] comment almond shell results and Perez et al. [40] discuss about pine bark, all of these studies were chosen due to their use of downdraft gasifiers for analysis. In addition, Tables 1 and 2 show marked differences between Buriti endocarp and other materials, such as: high content of volatiles and ash, highest $\mathrm{H} / \mathrm{C}$ ratio along with acai seed and lower lignin content. As consequence, BE gasification reactions are optimized with 1.7 equivalence ratio, closest number to stoichiometric value compared to other analyzed biomass types, resulting in lower $\mathrm{CO}$ and $\mathrm{CH}_{4}$ concentrations, also indicating that it may result in low tar and heavy hydrocarbons production.

Although Table 4 presents a comparison over synthesis gas species optimized concentrations, in comparison to other biomass types, it was important to analyze the equivalence ratio influence on species concentrations, as well as the adiabatic reaction temperature. Figure 6 shows numerical simulation results with variation in equivalence ratio as a function of species concentrations.

Hydrogen concentration increases with equivalence ratio $(\phi)$ up to maximum value of $12.29 \%$ for $\Phi=2.0$. Maximum $\mathrm{CO}$ concentration was obtained at 1.7 equivalence ratio. $\mathrm{CO}$ and $\mathrm{H}_{2}$ concentration values shown in Fig. 5 , for
Table 4 Comparison of published results $[17,27,40]$ with simulated results in the present work

\begin{tabular}{lcccc}
\hline Biomass & $\begin{array}{l}\text { Buriti endocarp } \\
\text { (This work) }\end{array}$ & Acai seed [16] & Almond shell [19] & Pine bark [18] \\
\hline $\mathrm{T}_{\text {gasification }}\left({ }^{\circ} \mathrm{C}\right)$ & 976.93 & 816.45 & 1486.85 & 813 \\
$\begin{array}{l}\text { Equivalence ratio }(\phi) \\
\text { air/biomass }\end{array}$ & 1.7 & 2.14 & 2.06 & 3.07 \\
$\mathrm{CO} \%$ vol & 9.6 & 14.4 & 17.56 & 17.29 \\
$\mathrm{CO}_{2} \%$ vol & 11.5 & 11.9 & 13.34 & 10.82 \\
$\mathrm{H}_{2} \%$ vol & 9.5 & 16.4 & 7.12 & 10.45 \\
$\mathrm{CH}_{4} \%$ vol & 0.18 & 0.4 & 1.01 & 0.21 \\
\hline
\end{tabular}


Fig. 6 Volumetric percentage of gas species resulting from the numerical simulation of Buriti Endocarp gasification

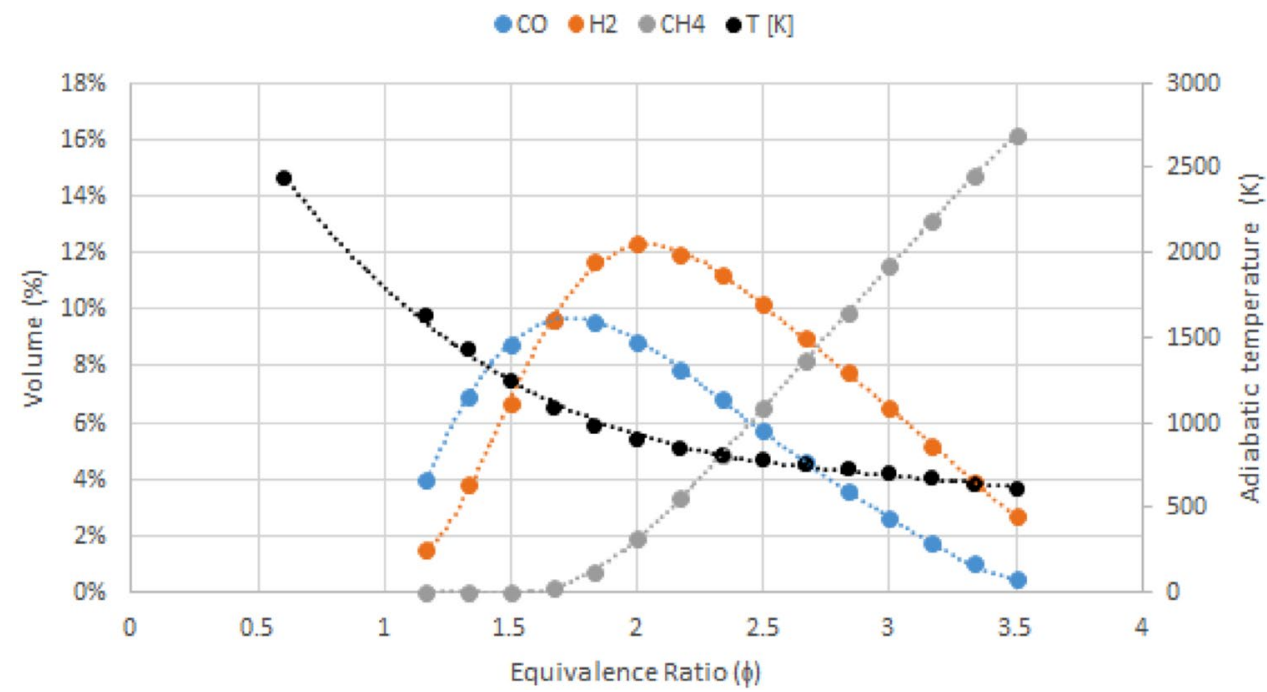

Table 5 Composition of the gasification gases of diverse biomasses

\begin{tabular}{lllll}
\hline Biomass & $\begin{array}{l}\text { Buriti endo- } \\
\text { carp (This } \\
\text { work) }\end{array}$ & $\begin{array}{l}\text { Acai seed } \\
{[16]}\end{array}$ & $\begin{array}{l}\text { Almond } \\
\text { shell* } \\
{[19]}\end{array}$ & $\begin{array}{l}\text { Pine bark* } \\
{[18]}\end{array}$ \\
\hline Air/ Biomass & 2.0 & 2.14 & 2.06 & 3.07 \\
$\mathrm{CO} \%$ vol & 14.4 & 11.30 & 14.48 & $16.17-26.98$ \\
$\mathrm{CO}_{2}, \%$ vol & 11.5 & - & 11.55 & $6.92-15.28$ \\
$\mathrm{H}_{2} \%$ vol & 17.5 & 12.80 & 8.58 & $12.76-20.75$ \\
$\mathrm{CH}_{4} \%$ vol & - & 1.30 & 3.85 & $1.16-3.70$ \\
\hline
\end{tabular}

*Downdraft gasifier

equivalence ratio between 1.7 and 2.0, indicate optimal gasification condition for both gases. For $\phi$ values between 1.7 and 2.0, the adiabatic temperature $(\mathrm{T})$ was respectively $976.93 \mathrm{~K}$ and $902.22 \mathrm{~K}$. It is observed that $\mathrm{T}$ values decrease constantly with rising $\phi$, that is, for pyrolysis conditions (high $\phi$ values) the reaction becomes endothermic, with significant $\mathrm{CH}_{4}$ production.

The simulation points out that it is possible to gasify this study chosen biomass with good $\mathrm{H}_{2}$ and $\mathrm{CO}$ values, important gases for this process; they are also responsible for the gas calorific power and consequently for its direct application in energy production. Finally, theoretical results obtained with the proposed model were compared with experimental results produced in these investigations, using a small-scale gasifier.

\subsection{Small scale gasification tests}

Once the model has been validated and optimal equivalence ratio $(\phi=2)$ has been found, a pilot-scale investigation proceeded on an updraft gasifier, aiming the experimental feasibility evaluation of Buriti waste syngas generation.

According to Hasler and Nussbaumer (1999) [41] and Han and Kim (2008) [42] the typical synthesis gas composition generated by gasification process in countercurrent reactors (updraft) using air as gaseous agent is the following one: $10-14 \%$ of $\mathrm{H}_{2}, 15-20 \%$ of $\mathrm{CO}, 8-10 \%$ of $\mathrm{CO}_{2}$ and $2-3 \%$ of $\mathrm{CH}_{4}$. Through the comparison, presented in Table 5, between the literature gases generated by gasification and the gas generated by the Buriti endocarp gasification, it is possible to conclude that the gasification process took significant place. The high $\mathrm{H}_{2}(17.5 \%)$ and $\mathrm{CO}$ (14.4\%) content exceeded the expectations presented by the applied simulation model. This result computes not only the possibility of generating energy from gas, supposing it is subjected to purification, but also shows its application in processes such as hydrocarbon production and other chemical processes with greater added value. The initial idea is primarily justified by the concept of energy generation, due to origin and context of the studied agroindustrial waste production. Of the components produced during reactions, $\mathrm{CO}, \mathrm{H}_{2}, \mathrm{CH}_{4}$ and hydrocarbons are energetically active. Other components, such as $\mathrm{CO}_{2}$ and $\mathrm{N}_{2}$, are inert and contribute to dilute the gas and reduce its calorific value.

Comparing numerical values, this study showed a discrepancy between obtained values, experimental results and other authors' predictions, as shown in Table 5. However, obtained values are acceptable for $0 D$ prediction model in fixed bed gasification phenomenon.

The simulated and experimental values results showed that volumetric $\%$ of produced gas in equivalence ratio of 2.0 presented the following composition: $\mathrm{CO}$-increased from 9.6 to $14.4 ; \mathrm{H}_{2}$-increased from 12.3 to $17.5 ; \mathrm{CO}_{2}$ decreased from 13.7 to 11.5 . This same behavior can be 
observed for almond shell [27] and pine bark [40] biomasses. About acai seed, the opposite of what is described in this work has occurred.

Itai et al. [16] reported that dissimilarity fact in experimental and theoretical results can be explained by several factors. One of them is that the proposed mathematical model does not take thermal losses into account, which partially explains this super prediction. If heat losses are considered, numerical results generally approach experimental ones. In that way, these models generally overestimate the $\mathrm{H}_{2}$ and $\mathrm{CO}$ yields, they underestimate $\mathrm{CO}_{2}$ yields and predict a free flow of $\mathrm{CH}_{4}$, tars and coal. Such facts may infer that a numerical analysis of the process shows minimum composition values of a gas produced by determined biomass conversion.

Pasangulapati et al. [43] reported that vegetal biomass chemical composition significantly influences the gas release profile in thermochemical processes, that being pyrolysis or gasification, concluding that high levels of cellulose and hemicellulose can generate higher $\mathrm{CO}$ and $\mathrm{CO}_{2}$ concentrations, and that high lignin levels can generate a higher $\mathrm{CH}_{4}$ concentration. Comparing $\mathrm{CO}$ and $\mathrm{CO}_{2}$ concentrations results obtained from Buriti endocarp with the ones from aforementioned literature, it can be concluded that Buriti generated gases richer in $\mathrm{CO}$, since its biomass showed a high holocellulose value $(69.64 \%)$ in chemical analysis.

The presented results were obtained in a small-scale gasifier that meets the perspective of studying biomass gasification process viability, beyond that, the used gasifier model and type largely matches the process type that can be used to convert residue at the place where it is generated. The small-scale reactors design may be associated with the used biomass intrinsic characteristics [44]. The general idea is to propose a system that meets regional context of agro-industrial residue production, which instead of being discarded can be converted into energy to feed the production and processing of fruits, seeds, among other inputs produced by this activity type.

\subsection{Sustainability and green energy technologies in Brazil}

The thermophysical assessment of residual biomass of Buriti as energy resource was presented in this work. However, the effective viability to make real the energy potential, depends on the availability of biomass, the energy conversion technologies, energy balance, and local government interest. From the point of view of availability and energy balance, two works $[45,46]$ indicate that biomass residues in Brazil represent a viable energy potential. Moreover, the biomass already plays an important role in Brazilian energy matrix. In 2020 , sugar cane products shared $18 \%$ of the
Brazilian energy matrix and the total biomass shared $8.4 \%$ of the electric energy matrix. Lora and Andrade [45] evaluated the importance of biomass in the Brazilian energy matrix and the biomass electric energy generation potential for sugar and alcohol sector, paper and cellulose sector, agricultural residues, timber residues, energy forests, and oleaginous plants. It is worth to notice that residual biomass from Buriti is in the category of oleaginous plants. The study of Ferreira-Leitão et al. [46] evaluated the potential uses of biomass residues not only for electric energy generation, but to produce renewable fuels and chemicals. The authors [46] analyzed the potential residues of sugar cane, soya, citrus, cassava, corn, coconut, rice, wheat, and compared the Brazilian biomass potential to several countries and regions of the World, also presenting the consolidated technologies of conversion. However, differently from Lora and Andrade [45], the work of Ferreira-Leitão et al. [46] did not indicate subsidies or how local government could make viable the use of biomass residues as energy, fuels or chemicals. Hall et al. [47] analyzed the use of biomass energy in developing countries, including Brazil, and more recently Rosillo-Calle [48] reviewed six main issues affecting biomass energy. Among those issues, is worth to mention the sustainability, subsidies, and energy balance.

Concerning the energy conversion technologies, most of the biomass wastes in Brazil are used in combustion process of thermal power plants with high installed power above $1 \mathrm{MW}$, and some above $100 \mathrm{MW}$. Gasification systems are better option for installed power less than $1 \mathrm{MW}$. Moreover, the commodity chain of Buriti is based on small communities production that are mostly isolated from the electric grid and need to generate their electricity using diesel generators [16, 49-51]. The Brazilian Amazon and Midwest regions have hundreds of small communities in this same scenario of electric isolation, availability of biomass wastes from the process of forest products, and the use of a diesel generator. Even for those small communities, the energy balance is positive when replacing the diesel energy by the energy of biomass residues, both in combustion systems with steam turbine power plants and gasification reactor connected to an internal combustion engine generator [22].

Sustainability is based on three dimensions: environment, social and economy. Therefore, the use of biomass wastes and substitution of diesel by renewable energy, sustains the environmental dimension. The economy is easily sustained in those communities due to the process of Buriti products and would improve if the residual biomass could be used as energy resources. The energy aggregated value for the wastes may represent more economic development based on the energy intensity definition, that the GDP and energy use are correlated. At 
the same time, the investment costs are elevated for the installation of a thermal power plant in small communities to use Buriti as energy source. In contrast, gasification systems with internal combustion engine generators have average installed power lower than the thermal power plants and need less investment costs. Therefore, gasification systems are more accessible to the small Brazilian communities that live based on the economy of the Buriti. In terms of social sustainability, the Brazilian experiences in Amazon region have shown that energy systems installed in isolated communities improved the local production of wood, fruits, oil and fish, increasing the number of jobs, the income and housing $[49,50]$.

Nevertheless, the biofuel programs implemented by Brazilian government, such as ethanol and biodiesel, have confirmed that government subsidies are essential in the beginning to subsequently reach a condition of a selfsustained sector. Brazilian government can promote the integration of the chain of Buriti products with sustainable energy generation in small communities using the biomass residues as energy sources. The Brazilian government have expertise in implementing similar programs such as "Light for All" (Luz para Todos, in Portuguese) that invested in energy generation integrated to the local production in small communities in Amazon region [49, 50]. The Program "Light for All" was active from 2003 to 2014, provided electricity access to more than 14 million people in Brazil, and specifically 3 million people in the Amazon Basin. Yet, there are still circa one million people living without electricity in the Amazon region [51].

In conclusion, the use of Buriti biomass residues would be viable from the point of view of the energy conversion technologies presented in this work, with positive energy balance. Also, the use of Buriti residual biomass as energy source would offer sustainability. Yet, only local government subsidies would leverage and make real the energy potential of biomass residues such as Buriti.

\section{Conclusions}

Previous knowledge about the main physicochemical characteristics of Buriti endocarp was essential for planning its residue use through harnessing energy route. By presenting low extractive content, high volatile content, high calorific value and a sufficient amount of lignin content, gasification technology aiming synthesis gas generation has been proposed. The use of mathematical models before experimental application indicated a good synthesis gas composition for Buriti gasification process and found that the best equivalence ratio for this biomass was 2.0, in which $\mathrm{H}_{2}$ and $\mathrm{CO}$ concentrations are theoretically at their maximum. Following experimental gasification tests, it was confirmed that the simulation presented a satisfactory forecast of the gasifier performance, and simulation obtained results, using the proposed model, demonstrate to be in accordance with experimental data.

As a result, Buriti endocarp incorporates the generation of potential income for rural extractive community, representing an alternative for communities that works with derivative activities from Buriti fruit to access energy sources from their waste, depending less on diesel acquisition and promoting its energy independence, circular economy and sustainability to the community.

Acknowledgements This work was supported by Coodenação de Aperfeiçoamento de Pessoal de Nível Superior (CAPES) under Financing Code 001, Fundação de Empreendimentos Científicos e Tecnológicos (FINATEC) and Decanato de Pesquisa e Pós-graduação da Universidade de Brasília (DPG/UnB) for financial support. We also would like to thank CNPq, Finep, IQ/UnB, LabCat/UnB, MCTIC, Petrobras, SDCT, FAPDF and the Network Marketing Partnership of Family Farmers and Gatherers of the Cerrado known as Cerrado Emporium.

Author contributions RBWE has written and analyzed the manuscript. MGG has performed the experiments and written the manuscript. GFG and ACMB helped in revising the manuscript.

\section{Compliance with ethical standards}

Conflict of interest The authors declare that they have no conflict of interest.

Ethical approval No animal work has been done in the manuscript.

Open Access This article is licensed under a Creative Commons Attribution 4.0 International License, which permits use, sharing, adaptation, distribution and reproduction in any medium or format, as long as you give appropriate credit to the original author(s) and the source, provide a link to the Creative Commons licence, and indicate if changes were made. The images or other third party material in this article are included in the article's Creative Commons licence, unless indicated otherwise in a credit line to the material. If material is not included in the article's Creative Commons licence and your intended use is not permitted by statutory regulation or exceeds the permitted use, you will need to obtain permission directly from the copyright holder. To view a copy of this licence, visit http://creativecommons .org/licenses/by/4.0/.

\section{References}

1. Zhang K, Pei Z, Wang D (2016) Organic solvent pretreatment of lignocellulosic biomass for biofuels and biochemicals: a review. Bioresour technol 199:21-33. https://doi.org/10.1016/j.biort ech.2015.08.102

2. Ghesti GF, Guimaraes MG, Evaristo RBW, Macedo JL, Nascimento PGBD (2019) Estudo prospectivo e tecnológico da celulose com ênfase em nanocelulose e catálise. Cadernos de Prospecção 12:577-589. https://doi.org/10.9771/cp.v12i3.26593

3. Zhang W, Huang S, Wu S, Wu Y, Gao J (2019) Study on the structure characteristics and gasification activity of residual carbon in biomass ashes obtained from different gasification 
technologies. Fuel 254:115699. https://doi.org/10.1016/j. fuel.2019.115699

4. Adeniyi AG, Ighalo JO, Onifade DV (2019) Production of bio- char from plantain (Musa paradisiaca) fibers using an updraft biomass gasifier with retort heating. Combust Sci Technol. https:// doi.org/10.1080/00102202.2019.1650269

5. Simone M, Barontini F, Nicolella C, Tognotti L (2012) Gasification of pelletized biomass in a pilot scale downdraft gasifier. Bioresour Technol 116:403-412. https://doi.org/10.1016/j.biort ech.2012.03.119

6. Pradhan P, Gadkari P, Mahajani SM, Arora A (2019) A conceptual framework and techno-economic analysis of a pelletizationgasification based bioenergy system. Appl Energy 249:1-13. https://doi.org/10.1016/j.apenergy.2019.04.129

7. Ismail TM, Monteiro E, Ramos A, Abd El-Salam M, Rouboa A (2019) An Eulerian model for forest residues gasification in a plasma gasifier. Energy 182:1069-1083. https://doi. org/10.1016/j.energy.2019.06.070

8. Guimaraes MG, Evaristo RBW, Brasil ACM, Viana NA, Itai Y, Macedo JL, Ghesti GF (2017) Evaluation of Brasilia wastewater sludge as a biomass resource for the production of energy by gasification simulation. Int J Sustain Eng 11:32-39. https://doi. org/10.1080/19397038.2017.1393025

9. Bertero M, García JR, Sedran U (2019) Thermochemical Processes Aimed at the Energy Valorization of Cow Manure from Feedlots. In: Advances in Feedstock Conversion Technologies for Alternative Fuels and Bioproducts. Woodhead Publishing. pp 317-338. Doi: https://doi.org/10.1016/B978-0-12-817937-6.00017-5

10. Trninić M, Stojiljković D, Manić N, Skreiberg O, Wang L, Jovović $A$ (2020) A mathematical model of biomass downdraft gasification with an integrated pyrolysis model. Fuel 265:116867. https://doi. org/10.1016/j.fuel.2019.116867

11. Silva DAD, Pena RDS (2018) Thermodynamic properties of Buriti (Mauritia flexuosa) tree gum. Food Sci Technol 38:390-398. https ://doi.org/10.1590/fst.02917

12. Cerrado ED (2020) Empório do Cerrado. Acess in:http://empor iodocerrado.org.br/

13. Cândido TLN, Silva MR (2017) Comparison of the physicochemical profiles of buriti from the Brazilian Cerrado and the Amazon region. Food Sci Technol 37:78-82. https://doi. org/10.1590/1678-457x.32516

14. Pardauil JJ, De Molfetta FA, Braga M, De Souza LK, Geraldo FNR, Zamian JR, Da Costa CEF (2017) Characterization, thermal properties and phase transitions of amazonian vegetable oils. JTherm Anal Calorim 127:1221-1229. https://doi.org/10.1007/ s10973-016-5605-5

15. Rodrigues PR, Araújo MF, Rocha TL, Veloso RVS, Pantoja LA, Santos AS (2018) Evaluation of buriti endocarp as lignocellulosic substrate for second generation ethanol production. PeerJ 6:5275. https://doi.org/10.7287/peerj.preprints.26777v1

16. Itai Y, Santos R, Branquinho M, Malico I, Ghesti GF, Brasil AM (2014) Numerical and experimental assessment of a downdraft gasifier for electric power in Amazon using açaí seed (Euterpe oleracea Mart.) as a fuel. Renew Energy 66:662-669. https://doi. org/10.1016/j.renene.2014.01.007

17. Evaristo RBW, Viana NA, Guimarães MG, Vale AT, Macedo JL, Ghesti GF (2020) Evaluation of waste biomass gasification for local community development in central region of Brazil. Biomass Convers Biorefin. https://doi.org/10.1007/s13399-02000821-y

18. Schutz FCA, Anami MH, Travessini R (2010) Desenvolvimento e ensaio de briquetes fabricados a partir de resíduos lignocelulósicos da agroindústria. Revista Eletrônica Científica Inovação e Tecnologia 1:3-8

19. Barakat A, Monlau F, Solhy A, Carrere H (2015) Mechanical dissociation andfragmentation of lignocellulosic biomass: effect of initial moisture, biochemical andstructural proprieties on energy requirement. Appl Energy 142:240-246. https://doi. org/10.1016/j.apenergy.2014.12.076

20. Ruiz JA, Juárez MC, Morales MP, Muñoz P, Mendívil MA (2013) Biomass gasification for electricity generation: Review of current technology barriers. Renew Sust Energ Rev 18:174-183. https:// doi.org/10.1016/j.rser.2012.10.021

21. Sikarwar VS, Zhao M, Clough P, Yao J, Zhong X, Memon MZ, Shah $\mathrm{N}$, Anthony EJ, Fennell PS (2016) An overview of advances in biomass gasification. Energy Environ Sci 9:2939-2977. https:// doi.org/10.1039/C6EE00935B

22. González CAD, Sandoval LP (2020) Sustainability aspects of biomass gasification systems for small power generation. Renew Sust Energ Rev 134:110180. https://doi.org/10.1016/j. rser.2020.110180

23. Sturion JA, Pereira JCD, Chemim MS (1988) Qualidade da Madeira de Eucalyptus Vimanalis Para Fins Energéticos Em Função Do Espaçamento e Idade de Corte. Boletim de Pesquisa Florestal, Colombo 16:55-59

24. Leandro RIM, Abreu JJDC, Martins CDS, Santos IS, Bianchi ML, Nobre JRC (2019) Elementary, chemical and energy characteristics of brazil nuts waste (Bertholletia Excelsa) in the State of Pará. Floresta e Ambiente. https://doi.org/10.1590/2179-8087.04361 8

25. Miranda MRS, Veras CAG, Ghesti GF (2020) Charcoal production from waste pequi seeds for heat and power generation. Waste Manag 103:177-186. https://doi.org/10.1016/j.wasma n.2019.12.025

26. Munalula F, Meincken M (2009) An evaluation of South African fuelwood with regards to calorific value and environmental impact. Biomass Bioenerg 33:415-420. https://doi.org/10.1016/j. biombioe.2008.08.011

27. Masmoudi MA, Halouani K, Sahraoui M (2017) Comprehensive experimental investigation and numerical modeling of the combined partial oxidation-gasification zone in a pilot downdraft air-blown gasifier. Energ Convers Manage 144:34-52. https:// doi.org/10.1016/j.enconman.2017.04.040

28. Rocha EPA, Gomes FJB, Sermyagina E, Cardoso M, Colodette JL (2015) Analysis of Brazilian biomass focusing on thermochemical conversion for energy production. Energ Fuel 29:7975-7984. https://doi.org/10.1021/acs.energyfuels.5b01945

29. Nogueira LAH, Lora EES (2003) Dendroenergia: fundamentos e aplicações. Interciência, Rio de Janeiro, p 199

30. Bonilla J, Gordillo G, Cantor C (2019) Experimental Gasification of Coffee Husk Using Pure Oxygen-Steam Blends. Front Energy 7:127. https://doi.org/10.3389/fenrg.2019.00127

31. Islam MA, Ahmed MJ, Khanday WA, Asif M, Hameed BH (2017) Mesoporous activated coconut shell-derived hydrochar prepared via hydrothermal carbonization- $\mathrm{NaOH}$ activation for methylene blue adsorption. J Environ Manage 203:237-244. https://doi.org/10.1016/j.jenvman.2017.07.029

32. Jara ERP (1989) O Poder Calorífico de Algumas Madeiras que ocorrem no Brasil. São Paulo: Instituto de Pesquisas Tecnológicas - IPT. (Comunicação Técnica, 1797)

33. Rambo MKD, Schmidt FL, Ferreira MMC (2015) Analysis of the lignocellulosic components of biomass residues for biorefinery opportunities. Talanta 144:696-703. https://doi.org/10.1016/j. talanta.2015.06.045

34. de Souza LM, Bezerra JB, de Queiroz WLV, Trugilho PF, de Paula PT, de Souza TM, Bufalino L (2020) Comparação da qualidade dos tecidos do pecíolo de buriti ( Mauritia flexuosa L.f.) para combustão e carbonização. Ciência Florestal 30:516-531. https://doi. org/10.5902/1980509839653

35. Conesa JA, Caballero J, Marcilla A, Font R (1995) Analysis of Different Kinetic Models in the Dynamic Pyrolisis of Cellulose. 
Thermochim. Acta 254:175-192. https://doi.org/10.1016/00406031(94)02102-T

36. Fengel D, Wegener G (2011) Wood: chemistry, ultrastructure, reactions. Walter de Gruyter.

37. Kim HS, Kim S, Kim HJ, Yang HS (2006) Thermal properties of bioflour-filled polyolefin composites with different compatibilizing agent type and content. Thermochim Acta 451:181-188. https ://doi.org/10.1016/j.tca.2006.09.013

38. Browne Fl (1958) Theories of the Combustion of Wood and its Control. Madison, A Survey of the Literature, FPL - Forest Products Laboratory, p 68

39. Martins H. (1982) Madeira como Fonte de Energia. In: PENEDO, W.R. Uso da madeira para fins energéticos. Belo Horizonte, M.G. CETEC - Centro Tecnológico de Minas Gerais, pp 9-26

40. Pérez JF, Melgar A, Tinaut FV (2014) Modeling of fixed bed downdraft biomass gasification: application on lab-scale and industrial reactors. Int J Energy Res 38:319-338. https://doi. org/10.1002/er.3045

41. Hasler PH, Nussbaumer T (1999) Gas cleaning for IC engine applications from fixed bed biomass gasification. Biomass Bioenerg 16:385-395. https://doi.org/10.1016/S0961-9534(99)00018-5

42. Han J, Kim H (2008) The reduction and control technology of tar during biomass gasification/pyrolysis: an overview. Renew Sust Energ Ver 12:397-416. https://doi.org/10.1016/j.rser.2006.07.015

43. Pasangulapati V, Ramachandriya KD, Kumar A, Wilkins MR, Jones CL, Huhnke RL (2012) Effects of cellulose, hemicellulose and lignin on thermochemical conversion characteristics of the selected biomass. Bioresour Technol 114:663-669. https://doi. org/10.1016/j.biortech.2012.03.036

44. Littlejohns JV, Butler J, Luque L, Kannangara M, Totolo S (2019) Analysis of the performance of an integrated small-scale biomass gasification system in a Canadian context. Biomass Convers Biorefin. https://doi.org/10.1007/s13399-019-00442-0
45. Lora ES, Andrade RV (2009) Biomass as energy source in Brazil. Renew Sustain Energy Rev 13:777-788. https://doi. org/10.1016/j.rser.2007.12.004

46. Ferreira-Leitão V, Gottschalk LMF, Ferrara MA, Nepomuceno AL, Molinari HBC, Bon EPS (2010) Biomass Residues in Brazil: Availability and Potential Uses. Waste Biomass Valor 2010(1):65-76. https://doi.org/10.1007/s12649-010-9008-8

47. Hall DO, Rosillo-Calle F, de Groot P (1992) Biomass energy: Lessons from case studies in developing countries. Energy Policy. https://doi.org/10.1016/0301-4215(92)90148-U

48. Rosillo-Calle F (2016) A review of biomass energy - shortcomings and concerns. Chem Technol Biotechnol 91:1933-1945. https://doi.org/10.1002/jctb.4918

49. Pinheiro G, Rendeiro G, Pinho J, Macedo E (2011) Rural electrification for isolated consumers: sustainable management model based on residue biomass. Energy policy 39:6211-6219. https:// doi.org/10.1016/j.enpol.2011.07.020

50. Andrade CS, Rosa LP, Silva NFD (2011) Generation of electric energy in isolated rural communities in the Amazon Region a proposal for the autonomy and sustainability of the local populations. Renew Sustain Energy Rev. https://doi.org/10.1016/j. rser.2010.09.052

51. Gómez MF, Silveira S (2015) The last mile in the Brazilian Amazon - A potential pathway for universal electricity access. Energy Policy. https://doi.org/10.1016/j.enpol.2015.02.018

Publisher's Note Springer Nature remains neutral with regard to jurisdictional claims in published maps and institutional affiliations. 